\title{
Effect of heat and nutritional stress on growth and testicular HSP70 expression in goats
}

\author{
P.A. ABDUL NIYAS ${ }^{1,2}$, V. SEJIAN ${ }^{1, *}$, M. BAGATH ${ }^{1}$, S. PARTHIPAN ${ }^{1}$, SELLAPPAN SELVARAJU ${ }^{1}$, \\ G. B. MANJUNATHAREDDY ${ }^{3}$, E.K. KURIEN ${ }^{2}$, GIRISH VARMA $^{4}$ and R. BHATTA ${ }^{1}$ \\ ${ }^{1} I C A R$ - National Institute of Animal Nutrition and Physiology, Adugodi, Bangalore \\ ${ }^{2}$ Academy of Climate Change Education and Research, Kerala Agricultural University, Vellanikkara, Thrissur, Kerala \\ ${ }^{3}$ ICAR-National Institute of Veterinary Epidemiology and Disease Informatics, Yelahanka, Bangalore-560064 \\ ${ }^{4}$ Centre for Animal Adaptation to Environment and Climate Change Studies, \\ Kerala Veterinary and Animal Sciences University, Mannuthy, Thrissur, Kerala \\ *Corresponding author E-mail:drsejian@gmail.com
}

\begin{abstract}
A study was conducted to assess the combined effects of heat and nutritional stress on body weight changes and HSP70 gene expressionin Osmanabadi goats. Twenty four adult Osmanabadi bucks were divided into four groups of six animals each viz. C (control), HS (heat stress), NS (nutritional stress) and CS (combined stress). The C and HS bucks had ad libitum access to their feed while NS and CS bucks were subjected to restricted feed ( $30 \%$ intake of $\mathrm{C}$ bucks) to induce nutritional stress. The $\mathrm{HS}$ and CS bucks were exposed to heat stress in outside environment for six hours a day between 10:00 $\mathrm{h}$ to 16:00 $\mathrm{h}$. Both $\mathrm{C}$ and HS groups showed significantly higher $(P<0.01)$ body weight and body condition scoring as compared to NS and CS groups. The highest plasma growth hormone $(P<0.01)$ was recorded in CS group and the lowest in all stress groups $(C, H S$ and NS). The higher $(P<0.05)$ expression of testicular Heat Shock Protein 70 (HSP70) mRNA was reported in HS groups. It can be concluded from this study that when nutrition is not compromised Osmanabadi goats were able to withstand heat stress without compromising production.
\end{abstract}

Key words : Osmanabadi bucks, heat stress, nutritional stress, spermatological traits, HSP70

In developing nations livestock plays a major role in the agricultural sector and it has a crucial role in deciding the economy of the nation. Small ruminants, like sheep and goats are integral part of livestock sector and it decides the livelihood of poor and marginal farmers in developing countries (Martello et al., 2010). Goats play a vital role in the livelihoods of small-scale farmers in developing countries. Climatic extremes and seasonal fluctuations in herbage amount and quality are considered as imperative source of influence on the well-being of goats in extensive production systems, which can impair reproduction and production efficiency of grazing animals (Martin et al., 2004). Therefore, grazing animals in extensive rearing can face nutritional imbalance during extreme summer months.

Livestock researchers aiming at improving livestock production under changing climatic scenario must aim at counteracting multiple stresses as these stresses are common occurrences in most ecological zones where livestock are reared (Sejian et al., 2010a). The projected climate change seriously hampers the pasture availability, especially, during the summers due to frequent droughts. Thus, livestock suffer from drastic nutrition deficiency. Both the quantity and the quality of the available pastures are affected during extreme environmental conditions (Sejian et al., 2010a). Hence, in addition to heat stress the deficit nutrition also need to be tackled. Further, the concept of multiple stresses emerges as a potential threat to livestock production and its survival (Sejian et al., 2011). Hence research needs to be prioritized to tackle multiple stresses simultaneously to improve the economy of the livestock farms.

Though the animals live in a complex world, researchers most often study the influence of only one stress factor at a time. Comprehensive, balanced, and multifactorial experiments are technically difficult to manage, analyze and interpret. When exposed to one stress at a time, animals can effectively counter it based on their stored body reserves and without altering the productive functions. However, if they are exposed to more than one stress at a time, the 
Table 1:Mean and SEM of climatological data during the experimental period inside and outside the shed

\begin{tabular}{lllllll}
\hline $\begin{array}{l}\text { Time of } \\
\text { recording }\end{array}$ & $\begin{array}{l}\text { Minimum } \\
\text { temperature }\left({ }^{\circ} \mathrm{C}\right)\end{array}$ & $\begin{array}{l}\text { Maximum } \\
\text { temperature }\left({ }^{\circ} \mathrm{C}\right)\end{array}$ & $\begin{array}{l}\text { Dry bulb } \\
\text { temperature }\left({ }^{\circ} \mathrm{C}\right)\end{array}$ & $\begin{array}{l}\text { Wet bulb } \\
\text { temperature }\left({ }^{\circ} \mathrm{C}\right)\end{array}$ & RH $(\%)$ & THI \\
\hline Inside the shed & & & & & & \\
Morning $(8: 00 \mathrm{hrs})$ & $21.5 \pm 0.6$ & $32.3 \pm 0.2$ & $23.8 \pm 0.2$ & $20.1 \pm 0.1$ & $78.6 \pm 4.6$ & $72.2 \pm 0.2$ \\
Afternoon $(14: 00 \mathrm{hrs})$ & $24.4 \pm 0.5$ & $35.6 \pm 0.7$ & $26.4 \pm 0.2$ & $20.9 \pm 0.1$ & $45.6 \pm 7.2$ & $74.7 \pm 0.2$ \\
Outside the shed & & & & & & \\
Morning $(8: 00 \mathrm{hrs})$ & $26.9 \pm 2.8$ & $34.0 \pm 0.5$ & $23.1 \pm 0.2$ & $22.9 \pm 0.6$ & $61.0 \pm 7.7$ & $73.9 \pm 0.5$ \\
Afternoon(14:00 hrs) & $27.2 \pm 3.4$ & $38.3 \pm 0.5$ & $29.5 \pm 0.3$ & $26.5 \pm 0.7$ & $37.0 \pm 4.1$ & $80.9 \pm 0.2$ \\
\hline
\end{tabular}

SEM-Standard error mean; RH- Relative humidity; THI- Temperature humidity index

summated effects of the different stressors might prove detrimental to these animals (Sejian et al., 2010a; Sejian et al., 2011). Such a response is attributed to animal's inability to cope with the combined effects of different stressors simultaneously. In such a case, the animal's body reserves are not sufficient to effectively counter multiple environmental stressors. However the influence of heat stress on biological functions and productive responses when coupled with long term nutritional stress in goats are not available in literature. In addition, despite the general awareness that energy demands vary between different seasons, only few quantitative data exist relating environment, nutrient need and productive efficiency in goats. Hence the present study was conducted to evaluate the influence of two environmental factors, heat and nutritional stress simultaneously on the growth and HSP70 gene expression in Osmanabadi goats.

\section{MATERIALS AND METHODS}

The experiment was carried out during April-May 2015 at the National Institute of Animal Nutrition and Physiology experimental livestock farm, Bengaluru, India.April-May2015.The average meteorological data for the entire study period both inside and outside shed are given in Table 1. The temperature humidity index (THI) values were calculated as per method described by McDowell (1972). The study was conducted for a period of 45 days. Twenty four adult bucks were randomly allocated into four groups of six animals each, C (control), HS (Heat Stress), NS (Nutritional Stress) and CS (Combined Stress). The animals were stall fed with a diet consisting of 60 per cent roughage (Hybrid Napier) and 40 per cent concentrate (maize $36 \mathrm{~kg}$, wheat bran $37 \mathrm{~kg}$, soya bean meal $25 \mathrm{~kg}$, mineral mixture 1.5 $\mathrm{kg}$ and common salt $0.5 \mathrm{~kg} / 100 \mathrm{~kg}$ of feed). The C and NS bucks were maintained in the shed where the maximum temperature the animals exposed was $35.6^{\circ} \mathrm{C}$ while $\mathrm{HS}$ and CS bucks were exposed outside to summer HS between 10:00 $\mathrm{h}$ to $16: 00 \mathrm{~h}$ where the maximum temperature $38.3^{\circ} \mathrm{C}$ with the difference of around $3{ }^{\circ} \mathrm{C}$ between inside and outside the shed. The $\mathrm{C}$ and HS bucks were provided with ad libitum feeding while NS and CS bucks were provided with restricted feed ( $30 \%$ of intake of ad libitum) to induce NS. All four group animals were fed and watered individually throughout the study period. All cardinal weather parameters were recorded both inside and outside the shed. Semen samples and blood samples were collected at fortnightly interval. The study was conducted after obtaining approval from the institute ethical committee for subjecting the animals to both HS and NS and for slaughtering the animals for collection of organs for histopathological section and gene expression.

\section{Blood collection, plasma separation and variables studied}

Two millilitres blood samples were collected at 15 days interval from all four groups simultaneously at 14:00 h using 20 gauge sterilized needles and plastic syringe from external jugular vein in tubes with heparin anticoagulant. Plasma was separated from blood by centrifugation at 3500 revolutions per minute (rpm) at room temperature for 20 minutes. The plasma was then divided into aliquots in microcentrifuge tubes, and kept frozen at $-20^{\circ} \mathrm{C}$ till further analysis. Plasma samples were used to estimate testosterone concentration.Body weight changes and body condition scoring ( 1 to 5 point scale) were recorded at 15 day intervals. Allometric measurements such as body length, height at withers and heart girth were also recorded at 15 days interval using a flexible tape in $\mathrm{cm}$. The endocrine parameter plasma growth hormone was estimated by enzyme linked immune sorbent assay kits (LDN, Nordhorn, Germany).

The testis samples were collected from all the animals 
Table 2:Effect of heat stress, nutritional stress and combined stresses (heat and nutritional) on body weight, body condition scoring and allometric measurements in Osmanabadi goats

\begin{tabular}{|c|c|c|c|c|c|c|c|c|}
\hline \multirow[t]{2}{*}{ Attributes } & \multicolumn{4}{|c|}{ Treatment } & \multirow[t]{2}{*}{ RSE } & \multicolumn{3}{|c|}{ P-Values } \\
\hline & $\mathrm{C}$ & HS & NS & $\mathrm{CS}$ & & $\mathrm{T}$ & $\mathrm{D}$ & $\mathrm{T} \times \mathrm{D}$ \\
\hline BW (kg) & $17.37^{\mathrm{a}}$ & $16.18^{\mathrm{a}}$ & $13.84^{\mathrm{b}}$ & $13.78^{\mathrm{b}}$ & 0.561 & 0.000 & 0.000 & 0.000 \\
\hline BCS (1-5 point) & $3.02^{\mathrm{a}}$ & $2.73^{\mathrm{b}}$ & $2.13^{\mathrm{c}}$ & $1.90^{\mathrm{c}}$ & 0.093 & 0.000 & 0.486 & 0.000 \\
\hline Heart girth $(\mathrm{cm})$ & $63.52^{\mathrm{a}}$ & $63.36^{\mathrm{ab}}$ & $61.84^{\mathrm{b}}$ & $59.50^{\mathrm{b}}$ & 0.920 & 0.038 & 0.134 & 0.000 \\
\hline Height at wither $(\mathrm{cm})$ & $62.16^{\mathrm{a}}$ & $60.77^{\mathrm{a}}$ & $58.80^{\mathrm{ab}}$ & $58.61^{\mathrm{b}}$ & 1.094 & 0.061 & 0.279 & 0.001 \\
\hline Body length $(\mathrm{cm})$ & $57.46^{\mathrm{a}}$ & $56.70^{\mathrm{a}}$ & $53.10^{\mathrm{b}}$ & $52.81^{\mathrm{b}}$ & 0.954 & 0.003 & 0.000 & 0.000 \\
\hline Growth hormone $(\mathrm{ng} / \mathrm{mL})$ & $1.44^{\mathrm{b}}$ & $1.65^{\mathrm{b}}$ & $1.89^{\mathrm{b}}$ & $2.77^{\mathrm{a}}$ & 0.147 & 0.000 & 0.022 & 0.004 \\
\hline
\end{tabular}

C-Control; HS-Heat Stress; CS-Combined Stress; CS-Combined Stress; Residual Standard Error; T-Treatment; D-Day; T x DTreatment and Experimental days interaction; BW-Body weight; BCS-Body Condition Scoring

Values bearing different superscripts within a row differ with each other at $\mathrm{P}<0.05$

in each group immediately after slaughter for expression of HSP70 in testicle. The total RNA was isolated from tissues using GeneJET RNA Purification Kit (Thermo Scientific, Lithuania) and the procedure was done as per manufacturer's protocol. The total RNA was reverse transcribed into cDNA using Maxima first strand cDNA synthesis kit for RT-qPCR (Thermo Scientific, Lithuania). Gene specific primers were designed using online NCBI primer design software (Primer 3, http://bioinfo.ut.ee/primer3/) and specificitywas checked using Primer3 and BLAST (http://www.ncbi.nlm.nih.gov/ tools/primer-blast/)The relative expression of selected genes was studied using SYBR green chemistry (Maxima SYBR green qPCR master mix, Fermentas, USA). The Glyceraldehyde 3-phosphate dehydrogenase (GAPDH) gene was used as an internal control and the relative expression

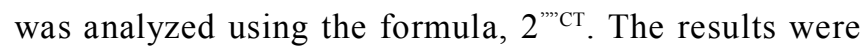
expressed in fold change as compared to untreated control (control=1 fold).

\section{Statistical analysis}

The data was analyzed by general linear model repeated measurement analysis of variance (SPSS16.0). Effect of fixed factors namely C, HS, NS and CS was taken as between subject factor and days (longitudinal time over which experiment was carried out; Day 0, Day 15, Day 30 and Day 45) were taken as within subject factor and also interaction between group and days was analyzed on the various parameters studied. Comparison of means of the different subgroups was made by Duncan's multiple range tests as described by Kramer, (1957). The changes in relative expression of testicle HSP70 mRNA in relation to GAPDH (Glyceraldehyde 3-phosphate dehydrogenase) as the house keeping gene were analyzed by one-way analysis of variance
(ANOVA) with Tukey's post-hoc analysis to compare the means between the groups. Results are shown as mean $\pm \mathrm{SE}$ from triplicates $(n=3)$. The significance level was set at $\mathrm{p}<0.05$.

\section{RESULTS AND DISCUSSION}

\section{Body weight, body condition scoring and allometric measurements changes}

The effects of HS, NS and CS on body weight, body condition scoring and allometric measurements are described in Table 2. Body weight recorded showed significant $(\mathrm{P}<0.01)$ changes for the treatment. There were significant $(\mathrm{P}<0.01)$ differences in body weight among the ad libitum (C and HS) and non-significant difference between restricted (NS and CS) feeding groups. Both C and HS groups differed significantly $(\mathrm{P}<0.01)$ in body weight as compared to restricted feeding groups (NS and CS). Further, experimental days significantly $(\mathrm{P}<0.01)$ influenced body weight throughout the study period. In addition, there was significant $(\mathrm{P}<0.01)$ interaction between groups and experimental days for the body weight in the study. Generally it is a well-established fact in small ruminants that the animals try to reduce their feed intake when subjected to HS in an attempt to reduce their metabolic heat production (Okoruwa, 2014). This may lead to reduction in their body weights. The significantly lower body weight in CS as compared to HS group could be attributed to the differences in their feed intake. This showed that the feeding schedule followed was able to successfully induce nutritional insufficiency in the present study. The CS and NS showed significant variations in body weight whereas HS did not influence body weight significantly as compared to $\mathrm{C}$ bucks. However, the same 


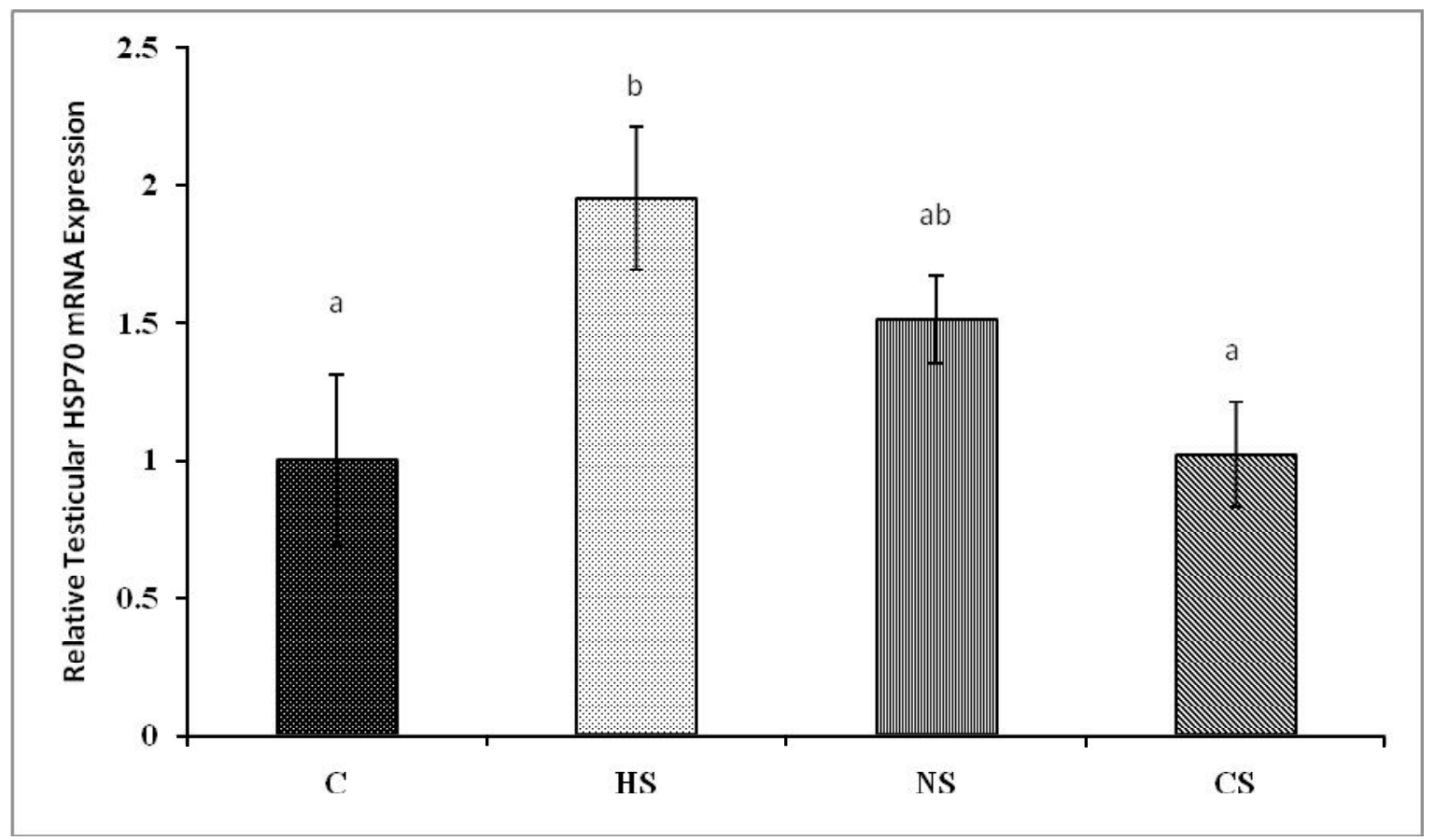

Fig.1: Testicular HSP70 mRNA transcript expression between the C (control), HS (heat stress), NS (nutritional stress), CS (combined stress- heat and nutritional) groups in Osmanabadi bucks. The highest HSP70 expression in testis was recorded in HS group. This level HSP70 expression in HS group was significantly higher than both C and MS groups. However HSP70 expression did not differ between HS and Ns groups. Values bearing different alphabets differ significantly with each other at $\mathrm{P}<0.05$

HS when coupled with restricted feeding was very detrimental to body weight. In a similar study on Malpura ewes, Sejian et al (2011) reported that HS alone did not influence body weight changes. However, both nutritional restriction and combination of heat and nutritional restriction was found to influence body weight significantly in their study. This showed that proper nutrition during thermal stress is more important to maintain body weight without much variation.

Body condition scoring recorded also showed significant $(\mathrm{P}<0.01)$ changes for the treatment. There were significant $(\mathrm{P}<0.01)$ differences in body condition scoring among the ad libitum (C and HS) and non-significant difference between restricted (NS and CS) feeding groups. Both $\mathrm{C}$ and $\mathrm{HS}$ groups differed significantly $(\mathrm{P}<0.01)$ for body condition scoring as compared to restricted feeding groups (NS and CS). However, experimental days did not influence body condition scoring in the study. But interaction between groups and experimental days differed significantly $(\mathrm{P}<0.01)$ for the body condition scoring in the study. The significant variation in BCS between groups showed the severity of nutritional restriction in inducing changes in
BCS. In a study conducted on Malpura sheep, Sejian et al (2010b) and Maurya et al (2010) reported the sensitivity of nutrient level in inducing changes in BCS under hot semiarid environment. The significantly lower BCS in CS as compared to HS group suggests the detrimental effects of cumulative effects of both HS and NS in CS group.

Heart girth recorded also showed significant $(\mathrm{P}<0.05)$ changes for the treatment. There were only significant $(\mathrm{P}<0.05)$ differences in heart girth in CS bucks as compared to other groups (C, HS and NS). However, experimental days did not influence heart girth in the study. But interaction between groups and experimental days differed significantly $(\mathrm{P}<0.01)$ for the heart girth in the study. Both treatment and experimental days did not influence height at withers in the study. However, interaction between groups and experimental days differed significantly $(\mathrm{P}<0.01)$ for the height at withers in the study. Length of the animal recorded between point of shoulder to pin bone showed significant $(\mathrm{P}<0.01)$ changes for the treatment. There were no significant differences in length among the ad libitum (C and HS) and restricted (NS and CS) feeding groups. However, length differed significantly $(\mathrm{P}<0.01)$ between ad libitum and 
restricted fed groups. Further, experimental days significantly $(\mathrm{P}<0.01)$ influenced length of the animals throughout the study period. In addition, there was significant $(\mathrm{P}<0.01)$ interaction between groups and experimental days for the length of the animal. The allometric measurements are body measurements which reflect the growth potential of an animal. Rana et al (2014) reported non-significant influence of HS on heart girth and length of the sheep. Similarly in current study also HS alone did not influence both heart girth and length of the animals. However, when both HS and NS are coupled they were able to bring significant changes in all allometric measurements in CS group. This shows the sensitivity of body measurements to nutrition level. Further, McManus et al (2009) reported significant influence of shoulder height, body length, and heart girth to reflect the adaptive capabilities of different breeds of dairy cattle.

\section{Endocrine parameters and heat shock protein 70 expression}

The effects of HS, NS and CS on plasma growth hormoneare described in Table 2. Plasma growth hormone level showed significant $(\mathrm{P}<0.01)$ variation between the groups. The highest plasma growth hormone was recorded in CS group and the lowest in rest all the groups (C, HS and NS). Further, the experimental days $(\mathrm{P}<0.05)$ and interaction between treatment and experimental days $(\mathrm{P}<0.01)$ also influenced plasma growth hormone concentration. The highest plasma GH concentration was recorded in CS group and this concentration was significantly different from other groups (C, HS and NS). Genetic and environmental factors are largely translated in hormonal signals affecting growth processes involving a complex sequence of interactions between different hormones (Kafi et al., 2012). Nutrition is one of the environmental cues that affect the somatic growth of ruminants (Thorn et al., 2006). In addition, nutrition is considered to be one of the prime regulators of the levels of GH and IGF-1 in livestock (Lee et al., 2006).

Testicular HSP70 mRNA transcript expression between the C, HS, NS and CS groups are described in Fig.1. The results revealed that testicular HSP70 mRNA expression was evident in C (1 fold), HS (1.95 fold), NS (1.51 fold) and CS (1.02 fold). On comparative basis, the higher $(\mathrm{P}<0.05)$ expression of testicular HSP70 mRNA was recorded in HS goats. This level of HSP70 mRNA expression in HS group was significantly $(\mathrm{P}<0.05)$ different only with $\mathrm{C}$ and $\mathrm{CS}$ groups. HSP70 is one of the most abundant and best characterized HSP family that consists of highly conserved stress proteins, expressed in response to stress, and plays crucial roles in environmental stress tolerance and adaptation in goats (Mohanarao et al., 2014).

\section{CONCLUSIONS}

The study identified that heat stress did not influence thebody weight, as compared to control group. This indicates that when nutrition is not compromised, the animals were able to withstand heat stress without compromising production. However, when heat stress was combined with nutritional stress in CS group, it had severe impact on growth and reproductive performance in Osmanabadi bucks. Further, the study signified the importance of nutritional status for HSP70 expression in testicles and this was evident from the higher HSP70 expression in HS group as compared to NS and CS group.

\section{ACKNOWLEDGEMENT}

The authors are grateful to Indian Council of Agricultural Research for funding this project and to the Director of the Institute for providing the research facilities.

\section{REFERENCES}

Kafi,M., Tamadon, A., Saeb, M., Mirzaei,A. andAnsari-Lari, M. (2012). Relationships between thyroid hormones and serum energy metabolites with different patterns of postpartum luteal activity in high-producing dairy cows. Anim., 6: 1253-1260.

Kramer, C.Y.(1957). Extension of multiple range tests to group correlated adjusted means. Biometrics., 13: 13-18.

Lee, H.G., Hong, Z.S., Kim, M.K., Kang, S.K., Xu, C.X., Cho, J.S., Seo, K.S., Rho, S.G. and Choi, Y.J. (2006). The response of plasma leptin and feed intake to growth hormone administration in Holstein calves with different planes of nutrition. Can. J. Anim. Sci., 86: 225-233.

Martello, L., Junior. H.S., Silva. S.L. \&Balieiro, J.C.C. (2010). Alternative body sites for heat stress measurement in milking cows under tropical conditions and their relationship to the thermal discomfort of the animals. Int. J. Biometeorol.,54: 647-652.

Martin, G.B., Rodger, J. and Blache, D.(2004). Nutritional and environmental effects on reproduction in small ruminants. Reprod. Fertil. Dev., 16: 491-501.

Maurya, V.P., Sejian, V., Kumar, D. and Naqvi, S.M.K. (2010). Effect of induced body condition score differences on sexual behavior, scrotal measurements, semen attributes and endocrine responses in malpura rams under hot 
semi-arid environment. J. Anim. Physiol. Anim. Nutr., 94: 308-317.

McDowell R.E.(1972). Improvement of livestock production in warm climate. WH Freeman and Co, San Fransisco, USA.

McManus, C., Paluda, G.R., Louvandini, H., Gugel, R., Sasaki, L.C.B.and Paiva, S.R. (2009). Heat tolerance in Brazilian sheep: physiological and blood parameters. Trop. Anim. Health. Prod., 41: 95-101.

Mohanarao, G.J., Mukherjee, A., Banerjee, D., Gohain. M., Dass. G., Brahma. B., Datta, T.K., Upadhyay, R.C. and De, S. (2014). HSP70 family genes and HSP27 expression in response to heat and cold stress in vitro in peripheral blood mononuclear cells of goat (Capra hircus). Small Rumin. Res., 116: 94-99.

Rana, M.S., Hashem, M.A., Akhter. S., Habibullah. M., Islam, M.H. and Biswas, R.C. (2014). Effect of heat stress on carcass and meat quality of indigenous sheep of Bangladesh. Bangladesh. J. Anim. Sci., 43: 147-153.

Okoruwa, M.I. (2014). Effect of heat stress on thermoregulatory, live bodyweight and physiological responses of dwarf goats in southern Nigeria. Eur. Sci. J., 10: 255-264.
Sejian, V., Bahadur, S. and Naqvi, S.M.K. (2014). Effect of nutritional restriction on growth, adaptation physiology and estrous responses in Malpura ewes. Anim. Biol., 64: 189-205.

Sejian, V., Maurya, V.P. and Naqvi, S.M.K.(2010a). Adaptability and growth of Malpura ewes subjected to thermal and nutritional stress. Trop. Anim. Health. Prod., 42: 17631770.

Sejian, V., Maurya, V.P. and Naqvi, S.M.K. (2010b). Adaptive capability as indicated by endocrine and biochemical responses of Malpura ewes subjected to combined stresses (thermal and nutritional) in a semi-arid tropical environment. Int. J. Biometeorol., 54: 653-661.

Sejian, V., Maurya, V.P. and Naqvi, S.M.K. (2011). Effect of thermal stress, restricted feeding and combined stresses (thermal stress and restricted feeding) on growth and plasma reproductive hormone levels of Malpura ewes under semi-arid tropical environment. J. Anim. Physiol. Anim. Nutr., 95: 252-258.

Thorn, S.R., Purup, S., Cohick, W.S., Vestergaard, M., Sejrsen, K. and Boisclair, Y.R. (2006). Leptindoes not act directly on mammaryepithelial cells in prepubertal dairy heifers. J. Dairy Sci., 89: 1467-1477. 